\title{
Effect of Biochar on Soil Health and Crop Productivity: A Review
}

\author{
P. Ramamoorthy ${ }^{1}$, P. Christy Nirmala Mary $^{2}$, K. Subas Chandra Bose ${ }^{3}$, \\ B. Karthikeyan ${ }^{1}$, K. Manivelan ${ }^{4}$
}

10.18805/ag.R-2379

\begin{abstract}
Biochar has been recently proposed as a management strategy to improve crop productivity and global warming mitigation. Biochar may be added to soils with the goal to improve the soil properties and relocate an amount of conventional fossil fuel based fertilizers and sequester carbon. Biochar production and incorporation in soil must play a role in climate change mitigation. The need for further clarity on optimizing biochar application to various crop yields is necessary if it is to gain widespread acceptance as a soil amendment. There is urgent need to intensify agricultural production to secure food supply for the ever increasing population especially in developing country like India of the tropics. Biochar proponents have placed on biochar stability in soil and it also includes increased soil fertility and water holding capacity, increased crop production and remediation of contaminated soils. The biochar have potential to feasibly and sustainably sequester/offset over $1 \mathrm{Pg}$ of $\mathrm{CO}_{2}$-carbon equivalents annually. Current carbon market incentives are not sufficient to rapidly increase or maximize the initiation and development of biochar implementation.
\end{abstract}

Key words: Biochar, Carbon sequestration, Soil amendment, Soil organisms, Soil properties.

Soil health is the foundation of a vigorous and sustainable food system. As the land is farmed, the agricultural process disturbs the natural soil systems including nutrient cycling and the release and uptake of nutrients (Skjemstad et al., 2002; Lal, 2004). Efficient use of biomass, available as crop residues and other farm wastes, by converting it to a useful source of soil amendment/nutrients is one way to manage soil health and fertility (DeLuca et al., 2006; Glaser et al., 2001). Biochar is a potential soil amendment and carbon sequestration medium. It also reduces farm waste and improves the soil quality.

The key role of agriculture now and in future is to provide safe and quality food for ever growing population. But agriculture is of more significance to global climate change and its effects on soil health and crop productivity. High yields often come from the use of improved crop varieties, fertilizers, pest control measures and irrigation, which have resulted in food and nutritional security (Lehmann et al., 2011). Despite high productivity, farmers see various problems associated with our intensive agricultural systems. It emphasizes the integration of biological, chemical and physical measures of soil quality that affect farmers profit and the environment. Efficient use of crop residue based amendment in soil is an important strategy to improve the soil fertility and productivity in rainfed areas.

Annually $500 \mathrm{Mt}$ crop residues are generated in India, out of which $141 \mathrm{Mt}$ is surplus. These residues are either partially utilized or un-utilized due to various constraints. Surplus and unused crop residues when left unattended, often disrupt land preparation, crop establishment and early crop growth and therefore are typically burnt on farm which causes environmental problems and substantial nutrient losses (Kannan Pandian et al. 2016). Efficient use of huge amount of biomasses, available as crop and agro forestry residues and other farm wastes by converting it in to a useful
${ }^{1}$ Department of Soils and Environment, Agricultural College and Research Institute, Tamil Nadu Agricultural University, Madurai625 001, Tamil Nadu, India.

2Department of Crop Management, Agricultural College and Research Institute, Kudumiyanmalai-622 104, Tamil Nadu, India. ${ }^{3}$ Department of Soil Science and Agrl. Chemistry, Tamil Nadu Agricultural University, Coimbatore-641 001, Tamil Nadu, India. ${ }^{4}$ Department of Plant Breeding and Genetics, Agricultural College and Research Institute, Tamil Nadu Agricultural University, Madurai625 001, Tamil Nadu, India.

Corresponding Author: P. Ramamoorthy, Department of Soils and Environment, Agricultural College and Research Institute, Tamil Nadu Agricultural University, Madurai-625 001, Tamil Nadu, India. Email: ramagri95@gmail.com

How to cite this article: Ramamoorthy, P., Mary, P.C.N., Bose, K.S.C., Karthikeyan, B. and Manivelan, K. (2022). Effect of Biochar on Soil Health and Crop Productivity: A Review. Agricultural Reviews. DOI: 10.18805/ag.R-2379.

Submitted: 16-09-2021 Accepted: 14-12-2021 Online: 20-01-2022

source of soil amendment. In this concern, biochar is an organic soil amendment, has emerged as a potential strategy to mitigate climate change, to maintain soil health and ensure the sustainable food production at the global scale.

\section{Biochar}

Biochar is a solid material obtained from thermo-chemical conservation of biomass in an oxygen limited environment (IBI, 2015). Biochar is a fine-grained, carbon-rich, porous product remaining after plant biomass has been subjected to thermo-chemical conversion process (pyrolysis) at temperatures $\left(\sim 350-600^{\circ} \mathrm{C}\right)$ in an environment with little or no oxygen. (Ameloot et al., 2015). The word Biochar is derived from Greek word. Bios means life; char means 
charcoal (product of carbonization of biomass). The term biochar was invented by Peter Read (lobbyists for biochar plantations). Biochar is a carbon material made by a process called pyrolysis and it is used as a soil amendment (Krull et al., 2006). It is the black carbon rich material derived by heating biomass with limited supply of oxygen. Unlike the original biomass, it contributes to long term removal of $\mathrm{CO}_{2}$ from atmosphere, since it is chemically and biologically more stable.

\section{Need of biochar research in India}

\section{a. Reduce the crop residue burning in the field}

Open field burning of crop residues is an age old practice to boost soil fertility in terms of $\mathrm{P}$ and $\mathrm{K}$, but it often leads to a loss of other nutrients such as $\mathrm{N}$ and $\mathrm{S}$, organic matter and microbial activity required for maintaining better soil health (IARI, 2012). But maintenance of threshold level of organic matter in rainfed soil is crucial to sustain soil physical, chemical and biological health. For more effective management and disposal of the crop and agro forestry residues, their conversion into biochar through thermochemical process (slow pyrolysis) is an alternative way of managing unusable and excess crop residues, examples of crop residues are given in Table 1 .

\section{b. To improve organic carbon in soil}

Biochar contains organic matter and nutrients, its addition increased soil $\mathrm{pH}, \mathrm{EC}$, Organic carbon in soil and thereby improves the soil fertility.

\section{c. To reduce $\mathrm{CO}_{2}$ rise in atmosphere}

The burning and natural decomposition of biomass and in particular agricultural waste adds large amounts of $\mathrm{CO}_{2}$ to the atmosphere. Biochar is a stable way of storing carbon in the ground for centuries, potentially reducing or stalling the growth in atmospheric green house gas levels.

Table 1: Loss of nutrients through crop residues.

\begin{tabular}{lcccc}
\hline \multirow{2}{*}{ Crop residue } & \multicolumn{3}{c}{ Loss of nutrient Mt/y } & \multirow{2}{*}{ Total } \\
\cline { 2 - 4 } & $\mathrm{N}$ & $\mathrm{P}$ & $\mathrm{K}$ & \\
\hline Rice & 0.236 & 0.009 & 0.200 & 0.45 \\
Wheat & 0.079 & 0.004 & 0.061 & 0.14 \\
Sugarcane & 0.079 & 0.001 & 0.033 & 0.84 \\
Total & 0.394 & 0.014 & 0.295 & 1.43 \\
\hline
\end{tabular}

\section{d. Environmental degradation}

Biochar helps in improving environmental quality by reducing soil nutrient leaching losses, reducing bioavailability of environmental contaminants, sequestering carbon, reducing GHG emissions and enhancing crop productivity in highly weathered or degraded soil.

\section{Impact of biochar on soil properties}

\section{Soil physical and chemical properties}

The physio-chemical properties are soil $\mathrm{pH}$, bulk density, water holding capacity, or cation exchange capacity of soils amended with biochar are positively increased. Khaled et al., (2019) conducted the field experiment in sandy soils with application of different rates of biochar viz.,10, 15 and $20 \mathrm{t}$ ha $^{-1}$ and concluded that the significantly increased water use efficiency (WUF), Crop Growth and Water Retention by 50 to 90 per cent, respectively as compared to the control like without biochar applied treatment, because the positive effect of $\mathrm{BC}$ treatments on water retention in the soil increased with increasing time of incubation and was greatest for the low pyrolysis temperature $\mathrm{BC}(\mathrm{BC} 300)$. This indicated that, as $\mathrm{BC}$ ages in soil, it can be more effective in promoting water retention, especially the low pyrolysis temperature. Patel and Yadav (2018) conducted the experiment in sandy soils in application of RDF along with Maize stover char @ $10 \mathrm{t} \mathrm{ha}^{-1}$ application recorded the significantly lower bulk density (1.05 $\mathrm{g} \mathrm{cm}^{-3}$ ) and also increasing the Water holding capacity of the soil all so positively significant of 28.27 per cent, these results are confirmed with the (Castaldi et al.,2011). Besides, the decrease in bulk density of biochar-amended soil could be one of the indicators of enhancement of soil structure or aggregation and aeration and could be soil-specific (Atkinson et al., 2010).

Kannan Pandian et al. (2016) conducted a field experiment in Alfisol of Semi-Arid tropics and the results are reported that soil application of red gram biochar improved the field-saturated hydraulic conductivity of the sandy soil, as result net water use efficiency also increased. At the same time chemical properties of soil also alter like soil $\mathrm{pH}$, total $\mathrm{C}$, total $\mathrm{N}$, Olson $\mathrm{P}$ and cation exchange capacity, because the applied biochar have more number of functional groups that are easily adsorbed the cation are strongly and increasing the nutrient availability of soils (Hong et al.,2014). Snekapriya and Jayachandran (2018)

Table 2: Summary of impact of biochar application on soil properties changes.

\begin{tabular}{lll}
\hline Soil properties & Findings & References \\
\hline Cation exchange capacity & $50 \%$ increased & Glaser et al., 2002, Liang et al., 2006 \\
Fertilizer use efficiency & $10-30 \%$ increased & Lehmann et al. 2007 \\
Crop productivity & $20-80 \%$ increased & Rangaswami et al. 2020 \\
Biological nitrogen fixation & $50-70 \%$ increased & \\
soil moisture retention & $18 \%$ increased & Kannan Pandian et al., 2016 \\
Mycorrhizal fungi & $40 \%$ incresed & Snekapriya and Jayachandran (2018) \\
Bulk density & Soil dependent & Patel and Yadav 2018 \\
Methane emission & $80 \%$ decreased & Segun et al., 2019 \\
\hline
\end{tabular}


conducted a research trial in sugar cane crop with application sugarcane trash biochar @ $2 \mathrm{t} \mathrm{ha}^{-1}$ along with grade levels fertilizer application and results are concluded that the longterm effect on biochar, the soil properties are positively increased because the biochar will be take time to mineralization and slowly released the nutrients and then crop will be easily increased uptake and availability of soils also increased the same findings also reported by Supriya et al., (2019) and Jin-Hua et al. (2011). Some important soil properties changes are given in Table 2.

\section{Soil biological properties}

Biochar pores and its high internal surface area which increased ability to absorb organic matter act as refuge for soil microbiota from predators and desiccation. The population of bacteria, actinomycetes and arbuscular mycorrhizal fungi increased due to application of biochar and this microbiota reduce $\mathrm{N}$ loss and increase nutrient availability for plants. The chemical stability of a large fraction of a given biochar material means that microbes will not be able to readily utilize the carbon as an energy source or the nitrogen and possibly other nutrients contained in the carbon structure.

Snekapriya and Jayachandran (2018) conducted a research trial on sugar cane with different grades of NPK $\left(50,75,100,125,150\right.$ per cent along with Biochar @ $\left.2 \mathrm{t} \mathrm{ha}^{-1}\right)$ and with biofertilizers (PSB and Rhizobium) in sandy soil and the results are reported that maximum microbial population was bactriea (33.16 cuf), fungi (10.25 cuf) and actinomycetes (17.44 cuf) observed in application of 150 per cent dose of NPK along with $2 \mathrm{t}$ of biochar + biofertilizer @ $10 \mathrm{~kg} \mathrm{ha}^{-1}$.Segun et al., (2019) tried with different levels of rice straw biochar application $\left(0,3,6\right.$ and $\left.12 \mathrm{t} \mathrm{ha}^{-1}\right)$ in sandy loam soil at Nigeria and observed that $12 \mathrm{t} \mathrm{ha}^{-1}$ of biochar application treatment significantly increasing higher soil enzyme activities. The increase in soil biological activity has been reported by Rondon et al. (2007) for nitrogen fixation in Phaseolus vulgaris and by Chan et al. (2008) for earthworm and microbial biomass. Biochar application to soil has long tradition provided evidence that it has positive effects on the abundance of mycorrhizal fungi.

\section{Impact of biochar on soils dynamics}

\section{Fertilizer use efficiency (FUE)}

Biochar function and its interaction with nutrient elements and crop roots may throw light on understanding fertilizer use efficiency. The enhanced nutrient retention capacity of biochar-amended soil not only reduces the total fertilizer requirements but also copes up the climate and environmental impact on crops (Chan and Xu, 2009). Biochar significantly increases the efficiency and reduces the need for traditional chemical fertilizers with sustainable crop yields. Biochar helps to improve soil resources by increasing crop yields and productivity by the way of reducing soil acidity and reducing the need for some chemical and fertilizer inputs (Yeboah et al. 2009). Longer-term benefits of biochar application on nutrient availability mainly due to a greater stabilization of organic matter, concurrent slower nutrient release from added organic matter and better retention of all cations due to a greater cation exchange capacity. High rates of biochar addition in the tropical environment have been associated with increased plant uptake of $\mathrm{P}, \mathrm{K}, \mathrm{Ca}, \mathrm{Zn}$ and $\mathrm{Cu}$ (Lehmann et al., 2007).

Biological nitrogen fixation by common beans was increased from 50 to $72 \%$ of total nitrogen uptake with increasing rates of biochar additions $(0,31,62$ and $93 \mathrm{tC}$ $\mathrm{ha}^{-1}$ ) to a low-fertility Oxisol (Rondon et al., 2007). Biochar also adds some macro ( $\mathrm{P}, \mathrm{K}, \mathrm{N}, \mathrm{Ca}$ and $\mathrm{Mg}$ ) and micronutrients $(\mathrm{Cu}, \mathrm{Zn}, \mathrm{Fe}$ and $\mathrm{Mn})$ which are needed for sustainable agriculture (Major et al., 2010). It may significantly affect nutrient retention and play a key role in a wide range of bio-geochemical processes in the soil, especially for nutrient cycling. A beneficial impact of biochar on the plant-available phosphorus has been observed in soils enriched with biochar, which in contrast to ammonium, is not a characteristic generally associated with soil organic matter (Lehmann et al., 2007; Steiner et al., 2007).

\section{Soil nutient leaching prevention}

Biochar has been found to decrease nutrient leaching thus enhancing nutrient availability (Chan et al. 2007). Higher nutrient availability for plant is the result of both the direct nutrient addition by the biochar and greater nutrient retention. Biochar may supply a source of plant-available nutrients once applied to the soil. This possibility is suggested by the strong adsorption affinity of biochar for soluble nutrients such as ammonium, nitrate, phosphate and other ionic solutes. Lehmann et al. (2007) found that "cumulative leaching of mineral $\mathrm{N}, \mathrm{K}$ and $\mathrm{Mg}$ in the soil was only 24,45 and $7 \%$, respectively, to control biochar (Krishna Veni et al., 2017). Results of the column leaching experiment showed that biochar addition significantly influenced $\mathrm{Na}^{+}$, $\mathrm{K}^{+}, \mathrm{Ca}^{++}$and $\mathrm{Mg}^{++}$concentrations in the leachate. For $\mathrm{Na}+$ concentration, no significant difference was found with biochar amendment under non-saline irrigation compared to respective non-biochar control.

\section{Modification of soil}

Biochar is commonly alkaline. The $\mathrm{pH}$ values of biochar at different pyrolysis temperature ranged from slightly alkaline (8.2) to highly alkaline (11.5) across a wide variety of feedstocks. Biochars shows positive effect in the case of acidic soils compared to alkaline soils (Biederman and Harpole, 2013). Biochar addition can reduce the bioavailability of toxic forms of $\mathrm{Al}, \mathrm{Cu}$ and $\mathrm{Mn}$ and increase the availability of essential nutrients such as $\mathrm{Na}^{+}, \mathrm{K}^{+}, \mathrm{Ca}^{++}, \mathrm{Mg}^{++}$ and Mo, thereby rendering a favourable environment for plant growth (Atkinson et al. 2010, Naresh Kumar et al., 2018). Among different treatments $60 \mathrm{~g} \mathrm{~kg}^{-1}$ of biochar application treatment was recorded the lowest exchangeable acidity this was followed by lime application @ $4 \mathrm{~g} \mathrm{~kg}^{-1}$ of soil and the control recorded highest exchangeable acidity of without biochar and lime application. This might be due to the soluble and exchangeable $\mathrm{Al}_{3}{ }^{+}$precipitates as insoluble hydroxyl Al-species at higher $\mathrm{pH}$ condition. Apart 
from increasing the incorporation of biochar to acidic soil can release their base cations which can participate in exchange reactions and replace the exchangeable $\mathrm{Fe}^{3+}, \mathrm{Al}^{3+}$ and $\mathrm{H}^{+}$on the soil surface and decrease the soil exchangeable acidity. Biochar can serve as a liming agent resulting in increased $\mathrm{pH}$ and nutrient availability for a different soil (Lehmann and Joseph 2007).

\section{Biochar application on crop yield}

Biochar on crop yield depend largely on the amount of biochar application and soil types. It is a positive effect on crop yield in general and it is more effective when applied to low to medium fertile soils (Chen et al., 2019). Liu et al. (2017) reviewed published data from 59 pot experiments and 57 field experiments from 21 countries and found crop productivity was increased by $11 \%$ on average. Liu found benefits at field application rates typically below $30 \mathrm{t} \mathrm{ha}^{-1}$, field application and reported that increases in crop productivity varied with crop type with greater increases for legume crops (30\%), vegetables (29\%) and grasses $(14 \%)$ compared to cereal crops corn (8\%), wheat $(11 \%)$ and rice (7\%). Combination of higher biochar application rates with NPK fertiliser increased crop yield on tropical Amazonian soils (Steiner et al., 2007) and semi-arid soils in Australia (Ogawa, 1994). Major et al., (2010) conducted a multiyear experiment in a maize - soybean rotation system and found that the maize yield was increased by 28 to 30 per cent in two years continuously cultivation. Several authors are confirmed the biochar application on crop yield will be increased are given in the Table 3.

\section{Carbon sequestration}

When it is added to soil, biochar has beneficial for growing crops; additionally biochar contains stable carbon (C) and after adding biochar to soil, this carbon remains sequestered for much longer periods than it would in the original biomass that biochar was made from. The biochar can rapidly increase the recalcitrant soil Carbon fraction of soil. Biochar also contains varying concentrations of other elements such as Oxygen (O), Hydrogen $(\mathrm{H})$, Nitrogen $(\mathrm{N})$, Sulfur $(\mathrm{S})$, Phosphors (P), base cations and heavy metals (Segun et al., 2019). The application of biochar had significantly influenced the soil OC content after 3 years of experiment in Alfisol, at the end of the experimentation control soil had only $3.6 \mathrm{~g}$ $\mathrm{kg}^{\prime 1}$ OC, whereas the soils that received different sources of biochar had soil OC content ranged between 4.4 and 4.8 $\mathrm{g} \mathrm{kg}^{\prime 1}$. Increase in the levels of biochar increased the content of OC, WSC (73\%) and BMC (37\%) in studied soil. (Kannan Pandian et al., 2016).

Biochar addition seems to generally enhance plant growth and soil nutrient status and decrease $\mathrm{N}_{2} \mathrm{O}$ emissions. Its amendment reduced $\mathrm{CO}_{2}$ production for all amendment levels tested $(2,5,10 \%, 20,40$ and $60 \%$ weight by weight basis; corresponding to 24 to $720 \mathrm{t} \mathrm{ha}^{-1}$ field application rates). The recalcitrance of the biochar suggested that it could be a viable carbon sequestration strategy and might provide substantial net GHG benefits with long lasting

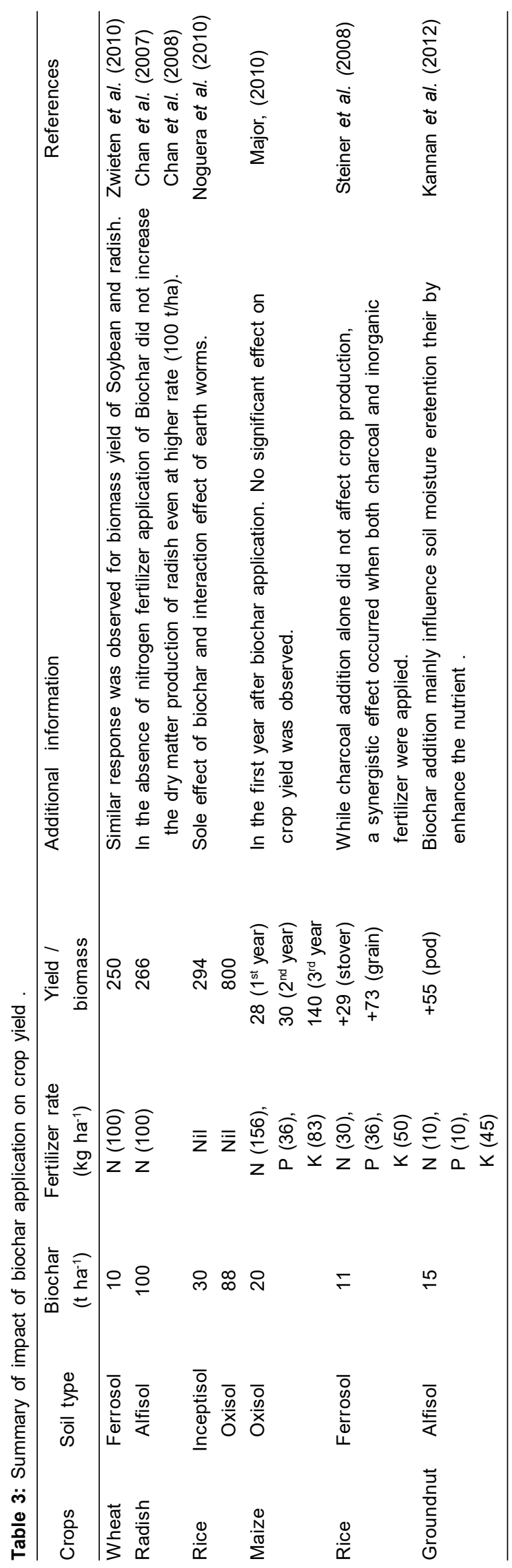

AGRICULTURAL REVIEWS 
reductions in $\mathrm{N}_{2} \mathrm{O}$ production. Biochar has potential to mitigate climate change as maximum of $1.8 \mathrm{mt}$ of $\mathrm{CO}_{2}$ equivalents per year without affecting food security and ecosystem. This is equivalent to $12 \%$ of current anthropogenic $\mathrm{CO}_{2}$ emissions annually (Woolf et al., 2010). The extent of this stimulation varies according to different estimates, being larger up to $60 \%$ in forest and smaller about $14 \%$ for pastures and crops. To assess the carbon sequestration potential of adding biochar to soil, we must consider four factors viz., the longevity of char in soil; the avoided rate of GHG emission; how much biochar can be added to soils and how much biochar can be produced by economically and environmentally acceptable means.

\section{Effect of biochar application}

\section{Adverse effect}

At this high application rate, yields decreased to the level of the unamended control. This is a very large amount that is unlikely to be practically feasible in the field, at least for a one-time amendment. However, Asai et al. (2009) working in Laos reported greater upland rice yields with $4 \mathrm{t} \mathrm{ha}^{-1}$ biochar, but when 8 or $16 \mathrm{t} \mathrm{ha}^{-1}$ were applied, yields were not different from the unamended control. A more recent field study on a poor, acidic soil of the USA showed that peanut hull and pinechip biochar applied at 11 and $22 \mathrm{t}$ ha ${ }^{1}$ could reduce corn yields below those obtained in the control plots, under standard fertilizer management (Gaskin et al. 2010).

\section{Residual effect}

The residual effect of biochar and mineral fertilizers was assessed using a mycorrhizal bioassay for soil collected from the field trial 2 years after application of biochar. Biochar and both fertilizers increased mycorrhizal colonisation in clover bioassay plants. Deep-banded biochar provided suitable conditions for mycorrhizal fungi to colonise plant roots (Sdaiman et al. 2010). The application of biochar @ $0,5,10$ and $20 \mathrm{~g} \mathrm{~kg}^{-1}$ soil with and without $5 \mathrm{~g} \mathrm{~kg}^{-1}$ of dried swine manure and results show that a significant decrease in the total amount of $\mathrm{N}, \mathrm{P}, \mathrm{Mg}$ and Si that leached from the manure amended columns as biochar rates increased but among columns receiving manure, the $20 \mathrm{~kg}^{-1}$ biochar treatments reduced total $\mathrm{N}$ and total dissolved $\mathrm{P}$ leaching by $11 \%$ and $69 \%$, respectively (Laird et al. 2010).

\section{CONCLUSION}

The soil health concept has increased awareness among agriculturist and horticulturist regarding the importance in maintaining soil fertility, crop productivity and environmental quality over a long term period. Biochar has positive effects on the physico-chemical and biological properties of soil, which means soil health directly and indirectly influenced with the application of biochar. The positive gains of biochar application in the soils include: retaining nutrients and cation exchange capacity, decreasing soil acidity, improving soil structure, nutrient use efficiency, water holding capacity, decreasing release of non- $\mathrm{CO}_{2}$ green house gases $\left(\mathrm{CH}_{4}\right.$, $\mathrm{N}_{2} \mathrm{O}$ ), increased number of beneficial soil microbes.

\section{REFERENCES}

Ameloot, N., Sleutal, S., Das, K.C., Kanagaratnam, J and Neve, S.D. (2015). Biochar amendment to soils with contrasting organic matter level. Effects of $\mathrm{N}$ mineralization and biological soil properties. Bioenergy. 7(1): 135-144.

Asai, H., Samson, B.K., Stephan, H.M., Songyikhangsuthor, K., Homma, K and Kiyono, Y. (2009). Biochar amendment techniques for upland production in Northern Soil physical properties, leaf SPAD and grain yield. Field Crop Research. 111: 81-84.

Atkinson, C.J., Fitzgerald, J.D. and Hipps, N.A. (2010). Potential mechanisms for achieving agricultural benefits from biochar application to temperate soils: A review. Plant Soil. 337(1-2): 1-18.

Biederman, L.A and Harpole. W.S. (2013). Biochar and its effects on plant productivity and nutrient cycling, a metaanalysis. GCB Bioenergy. 5: 202-214.

Castaldi, S., Riondino, M., Baronti, S., Esposito, F.R., Marzaioli, R., Rutigliano, F.A., Vaccari, F.P and Migliett, F. (2011). Impact of biochar application to a Mediterranean wheat crop on soil microbial activity and greenhouse gas fluxes. Chemosphere. 85:1464-1471

Chan, K.Y. and Xu, Z. (2009). Biochar: Nutrient Properties and Their Enhancement. In: Biochar for Environmental Management, Science and Technology, Earthscan, London. Pp. 67-84.

Chan, K.Y., Van Zwieten, L., Meszaros, I., Downie, A and Joseph, S. (2007). Agronomic valuses of green waste biochar as a soil amendment. Aust. J. Soil Res. 45: 629-634.

Chan, K.Y., Zwieten, V., Meszaros, L., Downie, I. and Joseph, S. (2008). Using poultry litter biochars as soil amendments. Austr. J. Soil Res. 46(5): 437-444.

Chen, W., Meng, J., Han, X., Lan, Y. and Zhang, W. (2019). Past, present and future of biochar. Biochar (Springer)1: 75-87.

DeLuca, T.H., MacKenzie, M.D., Gundale, M.J and Holben, W.E. (2006). Wild fire produced charcoal directly influences nitrogen cycling in forest ecosystems. Soil Sci. Soc. Am. J. 70: 448-453.

Gaskin, J.W., Speir, R.A., Harris, K., Das, K.C., Lee, R.D and Morris, L.A. (2010). Effect of peanut hull and pine chip biochar on soil nutrients, corn nutrient status and yield. Agronomy Journal. 102: 623-633.

Glaser, B. Lehmann, J. and Zech, W. (2002). Ameliorating physical and chemical properties of highly weathered soils in the tropics with charcoal- A review. Biol. Fertility. Soils. 35: $219-230$

Glaser, B., Haumaier, L., Guggenberge, G and Zech, W. (2001). The 'TerraPreta'phenomenon: a model for sustainable agriculture in the humidtropics. Nature wissenschaften. 88: $37-41$

Hong, Z., Xin-Hua, H., Tai-Qing, X., Bin, P. and Holden, N.M. (2014). Effect of Biochar Addition on Maize Growth and Nitrogen Use Efficiency in Acidic Red Soils. Pedosphere. 24(6): 699-708.

IARI, (2012). Crop residues management with conservation agriculture: Potential, constraints and policy needs. Indian Agricultural Research Institute. New Delhi: pp 32.

IBI. (2015) Standardized product defnition and product testing guidelines for biochar 6 that is used in soil. International Biochar Initiative. 
Jin-Hua, Y., Ren-Kou, X., Ning, W. and Jiu-Yu, L. (2011). Amendment of acid soils with crop residues and biochars. Pedosphere. 21(3): 302-308.

Kannan, P., Ponmani, S. and Swaminathan. (2016). Effect of biochar amendment on soil physical, chemical and biological properties and groundnut yield in rainfed alfisol of semiarid tropics. Archives of Agronomy and Soil Science; ISSN: 0365-0340 (Print). 1476-3567.

Kannan, P., Balasubramanian, P. and Prabukumar, G. (2012). Effect of biochar application on soil moisture retention, soil biology, growth and yield ofrainfed crops. Annual report 2011-2012. National initiative on climateresilient agriculture. Tamil Nadu Agricultural University. Pp. 38-49.

Khaled, D., Alotaibi and Schoenau. J. (2019). Addition of Biochar to a Sandy Desert Soil: Effect on Crop Growth,Water Retention and Selected Properties. Agronomys. 10: 1371.

Krishna Veni, D., Kannan, P. and Senthilkumar, A. (2017). Biochar from green waste for phosphate removal with subsequent disposal. Waste Management (Available online xxxx).

Krull, E.S., Swanston, C.W., Skjemstad, J.O. and McGowan, J.A. (2006). Importance of charcoal in determining the age and chemistry oforganic carbon in surface soils. J. Geophys. Res. P. 111 G04001, doi: 10.1029/2006JG000194.

Laird, D., Fleming, P., Wang, B., Horton, R. and Karlen, D. (2010). Biochar impact on nutrient leaching from a mid western agricultural soil. Geoderma.158: 436-442.

Lal, R. (2004). Soil carbon sequestration impacts on global climate change and food security. Science. 304: 1623-1627.

Lehmann, J. and Joseph. S. (2007). Biochar for environmental management: An Introduction. International Journal of Agricultural Science. pp. 1-12.

Lehmann, J., Gaunt, J and Randon, M. (2007). Biochar sequestration in terrestrial ecosystems-A review. Mitigation adaption Strategies. Global Change. 11: 403-427.

Lehmann, J., Rillig, M.C, Thies, J., Masiello, C.A., Hockaday, W.C and Crowley, D. (2011). Biochar effects on soil biota: A review. Soil Biol. Biochem. 43: 1812-1836.

Liang, B., Lehmann, J., Solomon, D., Kinyangi, J. and Grossman. J. (2006). Black Carbon increases cation exchange capacity in soils. Soil Science Society of America Journal. 70: 1719-1730.

Liu, Z., He, T., Cao, T., Yang, T., Meng, J and Chen, W. (2017). Effects of biocharapplication on nitrogen leaching, ammonia volatilization Biochar 13 and nitrogen use efciency in two distinct soils. J Soil Sci Plant Nut. https:/ /doi.org/10.4067/s0718-95162017005000037.

Major, J. (2010). Practical aspects of biochar application to tree crops. IBI Technical Bulletin 102, International Biochar Initiative. (Accessed online at http://www.biocharinternational. org/sites/default/files/Technical\%20Bulletin\%20Biochar\% 20Tree\%20Planting.pdf).

Major, J., Rondon, M., Molina, D., Rinha, S.J. and Lehman, J. (2010). Maize yield and nutrition during 4 year after biochar application to a Colombian savanna oxisol. Plant and Soil. 333:117-128.

Naresh Kumar, Y., Vijay Kumar, K.R., Sharma, R.S., Choudhary, T.S., Butter, G., Singh, Manoj Kumar and Rakesh Kumar. (2018). Biochar and their impacts on soil properties and crop productivity: A review. Journal of Pharmacognosy and Phytochemistry. 7(4): 49-5.
Noguera, D., Rondon, M., Laossi, K.R., Hoyos, V., Lavelle, P., Carvalho, M.H.C. and Barot,S. (2010). Contrasted effect of biochar and earthwormon rice growth and resource allocation in different soils. Soil Biol. Biochem. 42: 1017-1027.

Ogawa, M. (1994). Symbiosis of people and nature in the tropics. III.Tropical agricultureusing charcoal. Farming Jpn. 28: 21e35.

Patel, P.C and Yadav, S.N. (2018). Biochar preparation and effect of biochar on corn growth, yield, nutrient uptake and soil sustainability. M.Sc., Thesis.

Rangaswami, M.N., Banik, G.C., Rakesh, S. and Uma, K.T. (2020). Effect of Straw Biochar on Soil Acidity and Phosphorus Nutrition in Wheat. International Research Journal of Pure and Applied Chemistry. 1-8.

Rondon, M.A., Lehmann, J., Ramirez, J. and Hurtado, M. (2007). Biologicalnitrogen fixation by common beans (Phaseolus vulgaris L.) increaseswith bio-char additions. Biol. Fertil. Soils.43: 699-708.

Sdaiman,Z.M., Blackwell, P., Abbott, L.K and Strorer, P. (2010). Direct and residual effect of biochar application on mycorrhizal root colonization, growth and nutrition of wheat. Soil Research. 48(7): 546-554.

Segun, O., Adeyemo, A., Awodun, M., Ajayi, A. and Fasina, A. (2019). Effects of biochar and nitrogen fertilizer on soil physicochemical properties, nitrogen use efficiency and upland rice (Oryza sativa) yield grown on an Alfisol in Southwestern Nigeria. International Journal of Recycling of Organic Waste in Agriculture. 8: 295-308.

Skjemstad, J.O., Reicosky, D.C., Wilts, A.R. and McGowan, J.A. (2002). Charcoalcarbon in U.S. agricultural soils. Soil Sci. Soc. Am. J. 66: 1249-1255.

Snekapriya, V.K. and Jayachandran, M. (2018). Effect of sugarcane trash biochar on growth and yield of sugarcane seed crop. Madras Agric. J. 105(4-6): 147-150.

Steiner, C., Glaser, B., Teixeira, W.G., Lehmann, J., Blum, W. and Zech, W. (2008). Nitrogen retention and plant uptake on a highly weatheredcentral Amazonian Ferralsol amended with compost and charcoal. J. Plant Nutr. Soil Sci. 171: 893-899.

Steiner, C., Teixeira, W.G., Lehman, J., Nehls, T., Blum, W.E.H and Zech, W. (2007). Long term effect of manure, charcoal and mineral fertilizer on crop production and fertility on a highly weathered soil. Plant and Soil. 291: 275-290.

Supriya, M., Surama, N., Tanushree, D., Michael, A. and Pabitra, B. (2019). The impact of biochar on soil carbon sequestration: Meta-analytical approach to evaluating environmental an economic advantages. Journal of Environmental Management. 250: 109-112.

Woolf, D., Amonette, J.E., Street-Perrott, A., Lehmann, J. and Joseph, S. (2010). Sustainable biochar to mitigate global climate change. Nature Communications. 1: 56-64.

Yeboah, E., Ofri, P., Quqnsah, G.W., Dugan, E., Sohi. S.P. (2009). Improving soil productivity through biochar amendments to soil. Afr. J. Environ Sci. Technol. 3(2): 34-41.

Zwieten, V., Kimber, L., Morris, S., Chan, S., Downie, K.Y., Rust, A. and Cowie, A. (2010). Effects of biochar from slow pyrolysis of papermill waste on agronomic performance and soil fertility. Plant and Soil. 327(1): 235-246. 